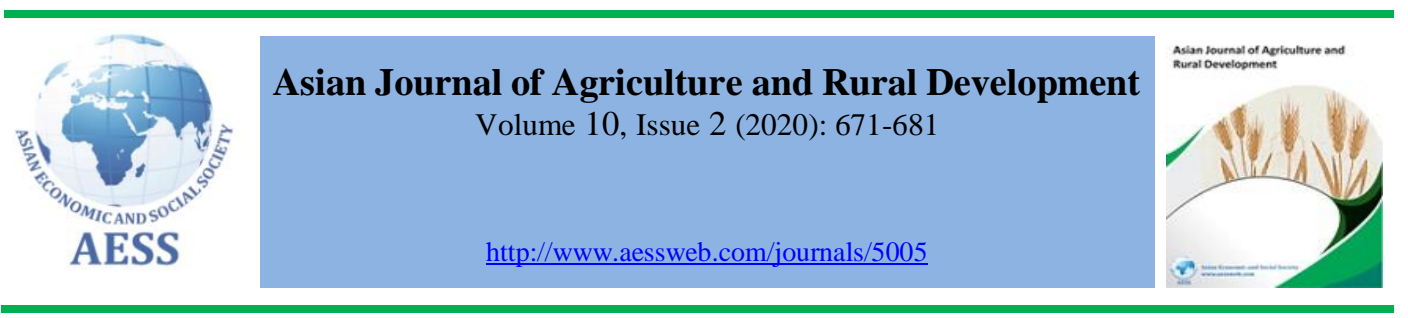

\title{
CHANGING PATTERN OF FARM AND NON-FARM LIVELIHOOD AMONG THE BODOS: A STUDY IN BODOLAND TERRITORIAL AREAS OF ASSAM, INDIA
}

\author{
Prithwiraj Swargiary a ${ }^{a}$ Ph.D. Scholar; Department of Economics, Dibrugarh \\ University, Assam, India \\ Amarjyoti Mahanta ${ }^{b}$ \\ ${ }^{\mathrm{b}}$ Associate Professor and Head; Department of Economics, \\ Dibrugarh University, Assam, India
}

- baramchari@gmail.com (Corresponding author)

\section{ARTICLE HISTORY: \\ Received: 21-Mar-2020 \\ Accepted: $31-\mathrm{Jul}-2020$ \\ Online Available: 03 -Sep- \\ 2020}

\section{Keywords:}

Bodos,

Livelihood,

Inter-generational,

Intra-generational

\begin{abstract}
The objective of this paper is to examine the pattern and intensity of inter-generational and intra-generational changes in livelihood, taking the case of the Bodos, the largest scheduled tribe of Assam, India. The data for the study has been collected from 1161 randomly selected Bodo households in Bodoland Territorial Area Districts of Assam. The intensity of inter-generational and intra-generational livelihood changes has been measured through a rate developed for the purpose. Further, the association between the livelihood attributes has also been tested. The study finds that the intensity of intra-generational livelihood change is less than that of the inter-generational change. Livelihood change is more prominent from the farm to the non-farm sector. Though livelihood changes have taken place between the generations, the sectoral selection of livelihood by the present generation is closely associated with the livelihood of the preceding generation. Steps for infrastructure development to unfold farm and non-farm sources of income are required. Agro-based industrial units should be promoted, and required skill development initiatives should be taken so those poor households can diversify their livelihood portfolios.
\end{abstract}

\section{Contribution/ Originality}

The paper explains the livelihood changes from the generational perspectives examining both intergenerational and intra-generational livelihood changes and contributes towards understanding the changes that have occurred in the traditional ways of living, giving due consideration to the areaspecific conditions. It explains a rarely addressed association between the main occupations pursued over the generations and within a generation over time.

DOI: 10.18488/journal.ajard.2020.102.671.681

ISSN(P): 2304-1455/ ISSN(E): 2224-4433

How to cite: Prithwiraj Swargiary and Amarjyoti Mahanta (2020). Changing pattern of farm and non-farm livelihood among the Bodos: a study in Bodoland territorial areas of Assam, India. Asian Journal of Agriculture and Rural Development, 10(2), 671-681.

(C) 2020 Asian Economic and Social Society. All rights reserved. 


\section{INTRODUCTION}

Livelihood refers to the ways and activities through which people achieve means of living, applying the capabilities and assets at their disposal. It is defined as the activities, assets, and access that jointly determine the living gained by an individual or household (Ellis, 1999). The means, activities, entitlements, and assets by which people gain a living, attempt to meet their consumption and economic needs, cope with uncertainties and respond to new opportunities are called livelihood (Chambers, 1995; Haan and Zommers, 2005). The activities are usually carried out repeatedly (Islam, 2014).

The capabilities, assets, and resources available to an individual or a group often influence the livelihood chosen by him or by the group. The resources available to the people living in rural areas are mostly agricultural or natural, and therefore, their primary livelihood is associated with agriculture and allied activities. However, inadequate irrigation facilities, crop failure, and more erratic market behavior for farm products increase the risk-sensitivity of farm income and make the agriculture-dependent livelihood strategy vulnerable and unsustainable. The growing importance of non-agricultural income has also raised a question on the extent to which agriculture is the key driver of rural development, and it is necessary to incorporate diversification in policies of rural development (Elmqvist and Olsson, 2006). Farm diversification has been considered as one of the most likely avenues to promote the development of agriculture (Seng, 2014). Farmers face difficulties in persisting with traditional productivist business models and have developed an entrepreneurial opportunity-seeking behavior (Morris et al., 2017). They attempt to assure income by undertaking a set of economic activities rather than relying upon a single source of income. The rural income diversification is seen to be higher among low-income people (Schwarze and Zeller, 2005). Rural people make a living through a portfolio of activities so that they can be flexible and can adapt to a wide range of misfortune and external shocks (Whitehead, 2002). If the main source of livelihood fails to provide sustainable income, households tend to opt for a diversified livelihood strategy for achieving rising income flows sustainably.

Household's livelihood strategy is interpreted as the chosen combination of assets, activities, and choices made usually at the household level to achieve their livelihood outcomes (Sallu et al., 2010; Rijn et al., 2012). A livelihood is socially sustainable if it can cope with and recover from stress and shocks and provide for future generations (Chambers and Conway, 1992). Sustainable livelihoods are stable, durable, resilient, and robust in the face of both external shocks and internal stresses (Scoones, 2009). In managing livelihood strategies, the household heads consider meeting the immediate consumption needs, managing long-term resources, investing in new technology, and people management as objectives (Whitehead, 2002). People tend to change the livelihood if they find it unsustainable. They counter the vulnerability arising out of risk and uncertainty of income to meet the present and future needs and aspirations by switching over to other activities.

The depletion of land resources for farming caused by the pressure of the population induces farm exit and motivates people to change livelihood in favour of non-farm activities. The presence of more family labourers increases the likelihood of farm exit for a different career (Ahmad et al., 2020). It is found that large farms provide higher incomes to farmers and, therefore, increase farm survival (Kimhi and Bollman, 1999). Farm households with a small size of operational land holding are more likely to change their livelihood strategies to non-farm occupations (Bhandari, 2013). Young and educated individuals prefer non-farm activities as occupation and hence, are more likely to change the occupation of the previous generation. Merlan (1998) pointed out that the young generation explores and internalizes new and diverse intercultural arenas of social practice. Remoteness is no longer an obstacle to the youth for broader cultural influences and they are more capable of adapting the modern non-farm occupation. Increasing opportunities brought about by modernization of agriculture, industrialization, development of services, urbanization, improvement in trade and commerce, an extension of market opportunities, etc. have motivated people to opt for non- 
traditional activities. Farm households also participate in non-farm activities and earn much more from non-farm activities than from the farm labor market (Reardon, 1997).

Conversely, the opportunities for off-farm income have grown much slower in comparison to the addition to the workforce in many developing countries (Binswanger-Mkhize, 2013; Agarwal and Agrawal, 2017). Therefore, many rural families do not change traditional agricultural occupations. In developing countries like India, for the majority of families in farm and non-farm sectors, agriculture has been the main source of livelihood (Acharya, 2006; Kumar et al., 2006).

This paper, therefore, seeks to examine the changes in the pattern of livelihood among the Bodos, the largest scheduled tribe of Assam. The Bodos are a branch of the Great Bodo Group of the IndoMongoloid family falling within the Assam-Burmese linguistic section (Bordoloi et al., 1987). As per the population census of India, 2011, the total Bodo population in Assam was 13,61,735, which was 35.06 percent of the total scheduled tribe population of Assam. Traditionally Bodos are agriculturists. However, over time, different occupational avenues have widened the employment opportunities. An earlier study (Swargiary and Mahanta, 2020) finds that the extent of livelihood diversification among the Bodos, measured in terms of Simpson index, is greater than that at the state level. Bodos are seen acquiring new ways of livelihood strategies that are adaptive to new technology and skills. Livelihood changes have been looked from the generational perspectives examining both inter-generational and intra-generational livelihood changes. While examining the changing pattern of livelihood among the Bodos, the paper seeks an answer to the research question - whether there is an association between the main occupation pursued by the present generation and the main occupation of the previous generation.

The livelihood changes affect the development discourse at the household and community level. Therefore, to understand the development discourse in a population, it is necessary to identify the directions of change in the livelihood strategy over the generations and within the same generation. This study is important for two reasons. Firstly, the Bodos are the largest scheduled tribe of the State of Assam whose source of livelihood has traditionally been agriculture. Like many other tribes, the Bodos use the local ecology, traditional knowledge, and organization for meeting the means of living. Understanding, therefore, the livelihood transition is of great use for understanding the changes that might have occurred in the traditional ways of living. Secondly, the Bodoland Territorial Council (BTC) was established in Assam in 2003 under the sixth schedule of the constitution of India covering four contiguous districts Baksa, Chirang, Kokrajhar, and Udalguri called as Bodoland Territorial Area Districts (BTAD). The local government of the area can formulate policies for efficient use of the workforce by providing alternative employment opportunities for a sustainable living giving due consideration to the area-specific conditions.

\section{DATA AND METHODOLOGY}

The data for the study has been collected from four districts that comprise the BTAD of Assam. The purpose of selecting BTAD is that it shelters 66 percent of the total Bodo population of the State. Samples have been drawn by following a multi-stage sampling procedure. The first stage of sampling design is the selection of sample sub-division from the sample districts. The sub-division with the highest proportion of the Bodo population of each district is selected as a sample. In the next stage, two Village Council Development Committees (VCDCs) are selected as samples from each sample sub-division based on the same population criterion. In the third stage, 50 percent of the total villages from each sample VCDC are chosen randomly as sample villages. Finally, 25 percent of the total Bodo households of each sample village are randomly selected. As such, 1161 households are covered for data collection using an interview schedule.

The rate of inter-generational livelihood change has been estimated through the following method: 


$$
\frac{N_{g 1 g 2}-N_{g 1=g 2}}{N_{g 1 g 2}} \times 100
$$

Where, $N_{g 1 g 2}=$ Total number of persons

$N_{g 1=g 2}=$ Number of persons of the current generation $(g 1)$ following the occupation of the previous generation $(g 2)$

Likewise, the intensity of intra-generational livelihood change is estimated as:

$$
\frac{N_{p c}-N_{p=c}}{N_{p c}} \times 100
$$

Where, $N_{p c}=$ Total number of persons

$N_{p=c}=$ Number of persons whose previous occupation $(p)$ and the current occupation $(c)$ is the same

The statistical significance of the association between the main occupation of the present and the previous generation and also between the present and previous main occupation of the present generation has been examined by the chi-square test.

\section{RESULTS AND DISCUSSIONS}

Agriculture is the primary occupation for most of the people of BTAD. The main occupation of the heads of the households has been categorized into two broad types - farm and non-farm occupation. The former covers the economic activities related to the agriculture and allied activities found in the sample households like farming, rendering service as agricultural labour, livestock rearing, and aquaculture. Activities like the salaried job, skilled profession, petty business, handicraft, and wage laborers are included in the non-farm category of occupation.

The study finds that the present main occupation of 38.5 percent of the heads of the sample households is in the farm sector, while 61.5 percent have the main occupation in the non-farm sector. In the farm sector, the majority of the respondents (i.e., 92 percent) are engaged in cultivation. On the other hand, most of the respondents with non-farm sector occupations are engaged in public and private salaried job (41 percent). However, this observed pattern of the current main occupation has evolved over time. The livelihood change over time has taken place within a generation and between the generations.

\subsection{Inter-generational livelihood change}

Inter-generational livelihood change refers to changes in livelihood status that occur between two generations, that is, of father and son or family members of one generation and the next (Chakravarty, 2013). Livelihood change will be called inter-generational if the present generation does not pursue the same occupation that was pursued by the preceding generation. In this study, the heads of the sample households are taken as the present generation while their fathers represent the preceding generation. Inter-generational change in livelihood sources will take place if the heads of the sample households follow an occupation different from that of their fathers. 
Table 1 depicts that out of the 1161 fathers of the heads of the sample households, 472 fathers had farming as the main occupation. However, it is found that only 64.19 percent of their sons (i.e., 303 sons) have continued the main occupation of their fathers, and the remaining 35.81 percent have changed their livelihood. It is stated that they have shifted to other occupations (mostly to salaried jobs) due to low income and other risks associated with the agriculture sector. Some household members migrated to other states and cities to work in non-farm activities. As in other studies (Sundaravaradarajana et al., 2011; Thapa and Yadav, 2015), lack of continuous employment is reported as the main reason for migration to urban areas.

It is found that only 12 percent of sons of the fathers whose main occupation was livestock have only continued the same occupation of their father and the remaining 88 percent of household heads have opted for other occupations. Inter-generational livelihood change could also be seen in the case of agricultural laborers. Findings show that as many as 90 percent of heads have not followed the same occupation of their father. They report that the wage rate of agricultural labour is highly fluctuating and seasonal. There is also no certainty of work available for wages. Hence, they have chosen an alternative income source.

\section{Table 1: Inter-generational livelihood change}

\begin{tabular}{|c|c|c|c|c|c|c|c|c|}
\hline \multirow{3}{*}{$\begin{array}{l}\text { Main occupation of the } \\
\text { household head }\end{array}$} & \multicolumn{8}{|c|}{ Main occupation of the father of the household head } \\
\hline & \multicolumn{3}{|c|}{ On-Farm } & \multicolumn{4}{|c|}{ Non-Farm } & \multirow[b]{2}{*}{ Handicraft } \\
\hline & Farming & Livestock & Agricultural labour & $\begin{array}{c}\text { Salaried job } \\
\text { (govt./Private) }\end{array}$ & $\begin{array}{l}\text { Wage } \\
\text { labour }\end{array}$ & Professional & $\begin{array}{c}\text { Petty } \\
\text { business }\end{array}$ & \\
\hline \multicolumn{9}{|l|}{ On-Farm } \\
\hline Farming & 303 & 4 & 11 & 14 & 38 & 4 & 38 & 0 \\
\hline Livestock & 3 & 3 & 1 & 0 & 5 & 0 & 0 & 0 \\
\hline Agricultural Labour & 2 & 0 & 6 & 0 & 7 & 1 & 4 & 3 \\
\hline \multicolumn{9}{|l|}{ Non-Farm } \\
\hline Salaried Job (govt./Private) & 106 & 5 & 15 & 22 & 120 & 2 & 19 & 2 \\
\hline Wage Labour & 21 & 7 & 25 & 2 & 212 & 4 & 8 & 3 \\
\hline Professional & 3 & 0 & 1 & 1 & 8 & 4 & 0 & 0 \\
\hline Petty Business & 31 & 6 & 2 & 2 & 49 & 2 & 13 & 5 \\
\hline Handicraft & 3 & 0 & 1 & 0 & 4 & 3 & 0 & 3 \\
\hline Total & 472 & 25 & 62 & 41 & 443 & 20 & 82 & 16 \\
\hline $\begin{array}{l}\text { Percentage of respondents } \\
\text { changing livelihood }\end{array}$ & 35.81 & 88.00 & 90.32 & 46.34 & 52.14 & 80.00 & 84.15 & 81.25 \\
\hline
\end{tabular}

Source: Survey data, 2019 
It is found that 41 fathers of the heads of the sample households had a salaried job (public/private sectors), but currently, only 54 percent of their sons are engaged in salaried jobs. Unlike their fathers, 46 percent heads of the sample households are now not engaged in salaried jobs as they have failed to get such employment opportunities. It is also found that 34 percent (i.e., 14) sample heads, whose fathers were salaried jobholders, are engaged in farming. Likewise, more prominent inter-generational livelihood change has been noticed from the occupation like different professions, petty business, and handicraft to other occupations.

The rate of inter-generational livelihood change has been estimated from the statistics presented in Table 1 by applying the following method:

$$
\frac{N_{g 1 g 2}-N_{g 1=g 2}}{N_{g 1 g 2}} \times 100
$$

Where, $N_{g 1 g 2}=$ Total number of persons $(\mathrm{N})$ which is 1161

$N_{g 1=g 2}=$ Total number of persons $(\mathrm{N})$ of the current generation continuing the same occupation of the previous generation $(g 1=g 2)$, which is 566 .

Hence, the rate of inter-generational livelihood change is $51.25 \%$.

Table 2: Inter-generational livelihood Change (Sectoral Analysis)

\begin{tabular}{lcccc}
\hline \multirow{2}{*}{$\begin{array}{l}\text { Main occupation of } \\
\text { the household head }\end{array}$} & \multicolumn{2}{c}{$\begin{array}{c}\text { Main occupation of the father of the } \\
\text { household head }\end{array}$} & Total & \multirow{2}{*}{$\boldsymbol{\chi}^{\mathbf{2}}$} \\
\cline { 2 - 4 } & On-Farm & Non-Farm & & \\
\hline On-Farm & $333(59.57)$ & $114(18.94)$ & 447 & \\
Non-Farm & $226(40.43)$ & $488(81.06)$ & 714 & 149.64 \\
Total & $559(100.0)$ & $602(100.0)$ & 1161 & \\
\hline
\end{tabular}

$\chi^{2}=149.64, \mathrm{p}=0.000 \leq 0.05, \mathrm{df}=1$

Figures in the parentheses indicate percentages

Table 2 shows that the main source of livelihood of the 559 fathers of the 1161 heads of the sample households was in the farm sector. It is seen that 59.57 percent of their sons have continued to earn a livelihood from the farm sector, while the rest of 40.43 percent of sons have changed their livelihood to the non-farm sector. Similarly, 602 fathers of the 1161 heads of the sample households had non-farm sector as the main source of livelihood. It has been found that 488 sons have continued to earn a livelihood from the non-farm sector, while the rest 114 have changed their livelihood to the farm sector.

To see if there is an association between the main occupation of the present generation and that pursued by the previous generation, the chi-square test has been done. The chi-square statistic is found significant at 1 percent level of significance, implying that there is an association between the main occupation of the previous generation and that opted by the present generation. It can thus be concluded that though livelihood changes have taken place between the generations, the sectoral selection of livelihood by the present generation is closely associated with the livelihood of the preceding generation.

\subsection{Intra-generational livelihood change}

Intra-generational livelihood change refers to change in someone's livelihood throughout his/her lifetime. In this study, livelihood change is interpreted as intragenerational if the household head currently pursues an occupation different from the occupation pursued previously. No 
intragenerational livelihood change shall occur if the present and previous occupation of the head of the household is the same.

Table 3 depicts the findings on the intragenerational livelihood change. It is found that out of the heads of the 1161 sample households, 455 were previously engaged in farming. Currently, 369 of them (i.e., 81.1 percent) have continued farming as the main occupation and the rest 18.9 percent have changed their current occupation. Intra-generational livelihood change among them has taken place chiefly to the salaried job in the public/private sector and petty business. It is reported that the risk faced by the farmers in gaining livelihood from agriculture has prompted them to shift to other occupations. People would have liked farming if the occupation was more profitable and less riskprone (Agarwal and Agrawal, 2017).

On the other hand, the percentage change in a livelihood within the generation is found as 25 percent and 53 percent in the case of livestock rearing and agricultural labour respectively. The change has taken place from agricultural labour to petty business, farming and salaried jobs.

Concerning the non-farm occupation, it is found that 7.65 percent of the respondents who were engaged previously in the salaried job have changed their livelihood. The majority of those sample heads who have changed the livelihood from salaried jobs were engaged in jobs in the unorganized sector and are now engaged basically in farming. On the contrary, the percentage change in a livelihood within the generation from wage labour, skilled professions and petty business categories of occupation to others is found as 30.76 percent, 44.83 percent and 16.42 percent, respectively. The change has taken place mostly in favour of salaried jobs and farming. It is found that all the sample heads pursuing handicrafts as the prime source of livelihood have not ever changed the source of livelihood. Thus, intragenerational livelihood change has not taken place in the case of handicraft occupation. 
Asian Journal of Agriculture and Rural Development, 10(1)2020: xxx

Table 3: Intra-generational livelihood change

\begin{tabular}{|c|c|c|c|c|c|c|c|c|}
\hline \multirow[b]{2}{*}{$\begin{array}{l}\text { Present Main } \\
\text { occupation of the } \\
\text { household head }\end{array}$} & \multicolumn{8}{|c|}{ Previous main occupation of the household head } \\
\hline & Farming & $\begin{array}{l}\text { On-Farm } \\
\text { Livestock }\end{array}$ & $\begin{array}{l}\text { Agricultural } \\
\text { labour }\end{array}$ & $\begin{array}{l}\text { Salaried job } \\
\text { (govt./private) }\end{array}$ & $\begin{array}{l}\text { Wage } \\
\text { labour }\end{array}$ & $\begin{array}{l}\text { Non-Farm } \\
\text { Professional }\end{array}$ & $\begin{array}{c}\text { Petty } \\
\text { business }\end{array}$ & Handicraft \\
\hline On-Farm & & & & & & & & \\
\hline Farming & 369 & 0 & 4 & 9 & 20 & 7 & 3 & 0 \\
\hline Livestock & 3 & 6 & 2 & 0 & 1 & 0 & 0 & 0 \\
\hline $\begin{array}{l}\text { Agricultural Labour } \\
\text { Non-Farm }\end{array}$ & 1 & 0 & 16 & 0 & 6 & 0 & 0 & 0 \\
\hline $\begin{array}{l}\text { Salaried Job } \\
\text { (govt./Private) }\end{array}$ & 51 & 2 & 4 & 169 & 59 & 4 & 2 & 0 \\
\hline Wage Labour & 8 & 0 & 3 & 3 & 261 & 1 & 6 & 0 \\
\hline Professional & 1 & 0 & 0 & 0 & 0 & 16 & 0 & 0 \\
\hline Petty Business & 22 & 0 & 5 & 2 & 24 & 1 & 56 & 0 \\
\hline Handicraft & 0 & 0 & 0 & 0 & 6 & 0 & 0 & 8 \\
\hline Total & 455 & 8 & 34 & 183 & 377 & 29 & 67 & 8 \\
\hline $\begin{array}{l}\text { Percentage of } \\
\text { respondents changing } \\
\text { livelihood }\end{array}$ & 18.9 & 25.0 & 53.0 & 7.65 & 30.76 & 44.83 & 16.42 & 0 \\
\hline
\end{tabular}

Source: Survey data, 2019 
The rate of intra-generational livelihood change is estimated from the data presented in Table 3 by applying the following method:

$$
\frac{N_{p c}-N_{p=c}}{N_{p c}} \times 100
$$

Where, $p=$ Previous occupation

$c=$ Current occupation

$N_{p c}=$ Total number of respondents $(\mathrm{N})$, i.e., the total number of heads of the sample households which is 1161

$N_{p=c}=$ Total number of persons (N) who have not changed their main source of livelihood. For this number of persons, previous occupation and the current occupation are the same $\left(p_{=} c\right)$, which is 901. Hence, the rate of intra-generational livelihood change is 22.39 percent.

Table 4: Intra-generational livelihood change (Sectoral Analysis)

\begin{tabular}{lccccc}
\hline \multirow{2}{*}{$\begin{array}{l}\text { Previous main occupation of } \\
\text { the household head }\end{array}$} & \multicolumn{2}{c}{$\begin{array}{c}\text { Current main occupation of the } \\
\text { household head } \\
\text { Non-Farm }\end{array}$} & Total & $\chi^{2}$ \\
& On-Farm & $96(13.45)$ & 497 & \\
\hline On-Farm & $401(89.71)$ & $618(86.55)$ & 664 & 211.74 \\
Non-Farm & $46(10.29)$ & $714(100.0)$ & 1161 & \\
Total & $447(100.0)$ & & \\
\hline
\end{tabular}

$\chi^{2}=211.74, \mathrm{p}=0.000 \leq 0.05, \mathrm{df}=1$

Figures in the parentheses indicate percentages

The study finds that 497 heads of the sample households previously had the main occupation in the farm sector while the number of household heads presently having the main occupation in the farm sector is 447. Likewise, 664 respondents were earlier engaged in the non-farm sector, while 714 respondents are currently working in the non-farm sector. Thus, intra-generational livelihood change has taken place from the farm sector to the non-farm sector. It is reported that the small landholding size, traditional agricultural technology, inadequate irrigation facility, seasonal nature of employment, crop failure and more erratic market behavior for farm products have increased the sensitivity of farm income to the risk and hence, farm income does not meet the rising needs.

It is also seen that 10.29 percent of the respondents currently having the main occupation in the farm sector has changed the main source of livelihood from the non-farm sector. But, 13.45 percent of the respondents currently engaged in non-farm sector has changed their livelihood from the farm sector to the non-farm sector. The majority of those who have changed the livelihood from the non-farm sector to the farm sector were engaged in jobs in the private and unorganized sector with low income. Therefore, they have preferred to engage in farming for the best utilization of their cultivable land. Failure in business has also caused some of them to change livelihood to farm-sector. The results indicate that though livelihood changes have taken place within the generations, the extent of change is less than the inter-generational change.

\section{CONCLUSION}

The study finds that inter-generational livelihood change from the previous generation to the present generation has taken place and it is more prominent from farm to non-farm sector, 
particularly to salaried jobs in public and private sectors. Inter-generational change in livelihood from the non-farm sector to the farm sector is found less significant. Although the fruits of industrialization and globalization have largely accrued to the urban areas, with development, urbanization and rapid modernization outlook on livelihood selection have changed even in rural areas. It was reported in the survey that the contact with the neighboring urban areas influenced their livelihood options. Unlike their parents, many respondents are not engaged in the salaried job due to lack of employment opportunities, required qualifications and skills lack.

Intra-generational livelihood change from the farm sector to the non-farm sector is more prominent than the change from the non-farm to the farm sector. Uncertainty of farm income due to inadequate irrigation facility, crop failure and more erratic market behavior for farm products have motivated people to shift occupation to non-farm sector. Low-paid jobs in the unorganized private sector, failure in business and willingness to utilize own cultivable land are the reported causes of change of livelihood from non-farm to farm sector. The study finds that the intensity of intragenerational livelihood change is less than that of the inter-generational change. The study also concludes that though livelihood changes have taken place between the generations, the sectoral selection of livelihood by the present generation is closely associated with the livelihood of the preceding generation.

Switching over of livelihood from farm to non-farm and vice versa does not necessarily ensure the wellbeing of the households. The key requirement is the better provision for basic infrastructure to unfold farm and non-farm sources of income for sustainable livelihood. Agro-based industrial units should be promoted to support the agriculture sector and create employment opportunities. Skill development initiatives should also be taken. The constraints of livelihood diversification are to be identified and addressed so that poor household can diversify their livelihood portfolios.

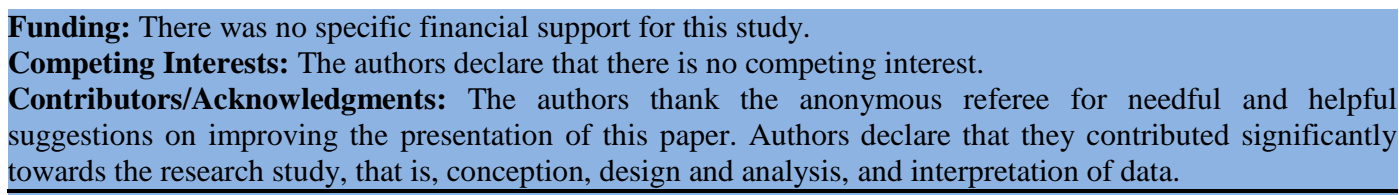
Views and opinions expressed in this study are the views and opinions of the authors, Asian Journal of Agriculture and Rural Development shall not be responsible or answerable for any loss, damage or liability, etc. caused in relation to/arising out of the use of the content.

\section{References}

Acharya, S. S. (2006). Sustainable agriculture and rural livelihoods. Agricultural Economics Research Review, 19, 205-217.

Agarwal, B., \& Agrawal, A. (2017). Do farmers really like farming? Indian farmers in transition. Oxford Development Studies, 45(4), 460-478. doi: 10.1080/13600818.2017.1283010.

Ahmad, M. I., Oxley, L., \& Ma, H. (2020). What makes farmers exit farming: a case study of Sindh province, Pakistan. Sustainability, 12(8), 1-17. doi:10.3390/su12083160.

Bhandari, P. B. (2013). Rural livelihood change? Household capital, community resources and livelihood transition. Journal of Rural Studies, 32, 126-136. doi.org/10.1016/j.jrurstud.2013.05.001.

Binswanger-Mkhize, H. P. (2013). The stunted structural transformation of the Indian economy: Agriculture, manufacturing and the rural non-farm sector. Economic Political Weekly, 58, 513.

Bordoloi, B. N., Sharma, T. G. C., \& Saikia, M. C. (1987). Tribes of Assam part -I. Tribal Research Institute, Assam, India.

Chakravarty, A. (2013). Intergenerational occupational mobility of the tribal people of Udalguri district: a Markov chain approach. International Journal of Innovative Research in Science, Engineering and Technology, 2(5), 1602-1603. doi.org/10.9756/bijiems.8300. 
Chambers, R. (1995). Poverty and livelihoods: Whose reality counts? Environment and Urbanization, 7(1), 173-204. doi.org/10.1057/9781137271631_8.

Chambers, R., \& Conway, G. (1992). Sustainable rural livelihoods: practical concepts for the $21^{\text {st }}$ century. IDS Discussion Paper 296. Institute of Development Studies, Brighton, UK.

Ellis, F. (1999). Rural livelihood diversity in developing countries: evidence and policy implications. Natural Resource Perspectives, 40(1), 1-10.

Elmqvist, B., \& Olsson, L. (2006). Livelihood diversification: continuity and change in the Sahel. GeoJournal, 67(3), 167-180.

Haan de, L., \& Zoomers, A. (2005). Exploring the frontier of livelihoods research. Development and Change, 36(1), 27-47.

Islam, N. (2014). Livelihood pattern of tribal and non-tribal people in Bangladesh: a case study on Rajshahi district (Doctoral dissertation). Sher-E-Bangla Agricultural University Sher-EBangla Nagar, Dhaka -1207.

Kimhi, A., \& Bollman, R. (1999). Family farm dynamics in Canada and Israel: the case of farm exits. Agricultural Economics, 21, 69-79. doi.org/10.1016/s0169-5150(99)00015-8.

Kumar, P., Singh, N. P., \& Mathur, V. C. (2006). Sustainable agriculture and rural livelihoods: a synthesis. Agricultural Economics Research Review, 19, 1-22.

Merlan, F. (1998). Caging the rainbow: places, politics and aborigines in a north Australian town. University of Hawai'i Press, Honolulu.

Morris, W., Henley, A., \& Dowell, D. (2017). Farm diversification, entrepreneurship and technology adoption: Analysis of upland farmers in Wales. Journal of Rural Studies, 53, 132-143.

Reardon, T. (1997). Using evidence of household income diversification to inform study of the rural nonfarm labor market in Africa. World Development, 25, 735-747.

Rijn, F., van Burger, K., \& Belder, E. (2012). Impact assessment in the Sustainable Livelihood Framework, Development in Practice, 22(7), 1019-1035.

Sallu, S. M., Twyman, C., \& Stringer, L. C. (2010). Resilient or vulnerable livelihoods? assessing livelihood dynamics and trajectories in rural Botswana. Ecology and Society, 15(4), p. 3.

Schwarze, S., \& Zeller, M. (2005). Income diversification of rural households in Central Sulawesi, Indonesia. In: Quarterly Journal of International Agriculture, 44(1), 61-73.

Scoones, I. (2009). Livelihoods perspectives and rural development. The Journal of Peasant Studies, 36(1), 171-196.

Seng, K. (2014). Determinants of farmers' agricultural diversification: the case of Cambodia. Asian Journal of Agriculture and Rural Development, 4(8), 414-428.

Sundaravaradarajana, K. R., Sivakumara, P., \& Jahanmohan, K. R. (2011). Determination of key correlates of agricultural labour migration in less resources endowed areas of Tamil Nadu. Agricultural Economics Research Review, 24, 467-472.

Swargiary, P., \& Mahanta, A. (2020). Extent of rural livelihood diversification: the case of the Bodos of Assam, India, Asia-Pacific Social Science Review, 20(1), 184-190.

Thapa, R., \& Yadav, S. K. (2015). Rural labour migration in India: magnitude and characteristics. International Journal of Applied Research, 1(2), 114-118.

Whitehead, A. (2002). Tracking livelihood change: theoretical, methodological and empirical perspectives from north-east Ghana. Journal of Southern African Studies, 28(3), Special Issue: Changing Livelihoods, 575-598. 